\title{
СОЦАЛЬНІ КОМУНІКАЦЇ̈
}

\author{
УДК 378:316.
}

DOI: 10.15587/2313-8416.2015.53956

\section{СОЦІОЛОГІЧНІ АСПЕКТИ ОСВІТИ В ГЕНЕЗІ МЕРЕЖНОГО СУСПІЛЬСТВА}

\section{(c) О. Л. Заміховська}

Розглянуто тенденції розвитку освіти в ракурсі основних підходів дослідження мережного суспільства. Досліджено становлення та розвиток мережного суспільства і мережної взаємодії, мережної комунікації. Спираючись на характерні риси та особливості мережевого суспільства, які виділяються різними дослідниками, розкрито вплив можливостей людської комунікації на організацію сучасної освіти

Ключові слова: інформаційне суспільство, мережа, мережеве суспільство, інформатизачія, інформаціийно-комунікаційні технології, інформаціональне суспільство

Tendencies of education development in the perspective of basic research approaches of networked society are considered. Formation and development of the network society, network interaction and network communication are investigated. Based on the characteristics and features of the network society, which are allocated by various researchers, an influence of human communication possibilities for the organization of modern education is revealed

Keywords: information society, network, network society, informatization, information and communication technologies, informational society

\section{1. Вступ}

Розвиток інформаційного суспільства в Україні пов'язаний з реорганізацією і пріоритетністю освітнього простору як основної сфери формування сучасного знання, головного чиннику прогресивного розвитку суспільства.

В основі концепції мережевого суспільства лежить уявлення про інформацію як знання, що породжує конструктивні зміни системи. Інформація розуміється як характеристика можливостей системи. Інформація $є$ знання обмеженості існуючих можливостей.

Генезис та розвиток інформатизації суспільства як процесу соціальної реальності пов язані з широким колом проблем взаємовідносин техніки, людини та суспільства. Домінантою розвитку сучасного суспільства стають знання. При цьому, процеси генерації нових знань, їх акумуляція, розповсюдження та використання є основними.

\section{2. Постановка проблеми}

Дослідження інформаційного суспільства в сучасних умовах трансформації соціуму потребують всебічного аналізу проблем глобалізації науки та освіти. Глобалізація $є$ одним 3 аспектів ширшого явища модернізації, який описує суспільства та характеризується зростанням прогресуючих складних комунікацій.

Інформатизація суспільства в наш час являє собою комплексний соціокультурний, соціотехніч- ний та соціально-історичний процес, який передбачає розвиток нової інформаційної культури і нової інформаційної цивілізації. Важливим $є$ те, що в контексті аналізу інформаційного суспільства інформаційну цивілізацію неможна розуміти як тільки соціальний або тільки технічний процес; необхідно розглядати аспекти інформатизації нерозривно пов `язаними.

У сучасному українському просторі відбувається інтенсивна реорганізація освітньої системи, що пов'язана 3 культурно-цивілізаційним розвитком та переходом людства до такої форми існування як інформаційне суспільство - «суспільство знань», де головним джерелом прогресу є знання, інформація.

Відтак, освітній комплекс стає важливим елементом сучасного суспільства, що забезпечує одержання нового економічного ресурсу інформаційного суспільства - знань.

\section{3. Літературний огляд}

Інформаційне суспільство слід розглядати в концепції постіндустріального суспільства, яке характеризується передусім розвитком виробництва інформаційних, а не матеріальних цінностей, де головними продуктами виробництва $є$ інформація і знання. Багато дослідників відзначають, що хоча інформація і продовжує відігравати значну роль в житті суспільства в контексті пізнання, поступово на провідні ролі виходить поняття коммунікації. Підтвердження цьому можна знайти в роботах М. Кастельса, де він говорить про те, що необхідно відмовитися від поняття 
«інформаційне суспільство» і визначати суспільство в світлі того, що дійсно буде новим в сучасну епоху, а саме через інформаційні мережі [1].

Філософи і соціологи у своїх роботах, присвячених сучасній постіндустріальній епосі, активно оперують поняттям мереженого або інформаційномережного суспільства. Ряд зарубіжних авторів, використовуючи концепцію постіндустріалізму, досліджували специфіку інформаційного суспільства в цілому. Серед найбільш значимих слід виділити праці Д. Белла (D. Bell), К. Вербаха (K. Werbach), Р. Кана (R. Kahn), Е. Кінга (Е. King), I. Масуди (Y. Masuda), Т. Меррілла (Т. Merrill), М. Пората (M. Porat), Л. Робертса (L. Roberts), К. Робінсона (K. Robinson), P. Peддіка (R. Reddick). Аналіз робіт, присвячених інформаційному суспільству, показує, в чому теоретики вбачають особливу роль знання (інформації) в сучасному суспільстві: інформація розглядається як виробничий ресурс, перехід до «інформаційно-ємного» продукту в епоху розвиненого капіталізму [2].

У зв'язку з тим, що технічною базою сучасного суспільства $є$ інформація, його ще називають інформаційним суспільством, в якому інтелектуальні технології, інформація, обробка знань посідають дедалі важливіші місця. Цей термін запровадив японський вчений I. Масуда. Д. Белл також виділяє головні риси постіндустріального суспільства. Для постіндустріальної стадії характерним є перехід від виробництва речей до виробництва послуг, причому послуг, які пов'язані, насамперед з освітою, науковими дослідженнями, охороною здоров'я та управлінням. Центральне місце в постіндустріальному суспільстві, відповідно Д. Беллу, посідають знання, причому знання теоретичні [3]. Відтак, І. Масуда, О. Тоффлер i Д. Белл практично прирівнювали інформаційне і постіндустріальне суспільство [4]

Мережне суспільство взяв за основу своїх досліджень американський соціолог М. Кастельс [1]. Мережеві принципи були в подальшому використані для аналізу суспільства в цілому, а саме сучасне суспільство стали часто називати постіндустріальним, інформаційним і мережним.

Питання вивчення сучасного інформаційного суспільства та суспільства знань $є$ актуальними, тому їм присвячено безліч робіт як вітчизняних, так і зарубіжних дослідників [5-13].

Проведені дослідження ставили за мету проаналізувати особливості соціологічних аспектів освіти у контексті становлення і розвитку мережевого суспільства і мережевої взаємодії, як сучасної високоефективної інноваційної технології.

4. Аналіз сучасного етапу розвитку інформаційного суспільства та його перехід на рівень мережевого

Кінець XX-початок XXI ст. характеризувався стрімким стрибком суспільства на стадію високих технологій і швидкістю їх освоєння, що неминуче призвело до змін у соціально-економічній сфері життя суспільства. Сутність техніки, їі місце та роль у суспільстві стали об'єктом пильної уваги філософської науки [14]. Наука, як особливий вид пізнавальної діяльності, спрямований на вироблення об'єктивних, істинних, системно організованих і обгрунтованих знань про оточуючий світ і суспільство, досягла значного розвитку. Становлення інформаційного суспільства призвело до всезагальної комп'ютеризації i введення інформаційно-телекомунікаційних технологій в усі сфери життя. В даному суспільстві знання та інформація відіграють неабияку роль, а отже і специфіка інформаціонального способу розвитку в тому, що головним джерелом виробництва в даному випадку є «вплив знання на саме знання» [1].

Поступово наукове співтовариство почало звертати увагу на нові виклики і проблеми, які несе бурхливий економічний і технологічний розвиток інформаційного суспільства. Було встановлено, що збільшення об'єму інформації не обов'язково призведе до приросту знань. Усе більш очевидним ставав той факт, що таке суспільство не гарантує якості і безпеки життя своїх громадян. «Усвідомлюючи глибокі протиріччя і загрози в розвитку інформаційного суспільства, мислителі стали активно здійснювати дослідження інших вимірів нового соціального порядку. Наслідком такого пошуку стало формування на рубежі століть концепції суспільства знань» [15]. Суспільство знань та інформації панує в світі і сьогодні.

3 розвитком інформаційно-комунікаційних технологій, мережі Інтернет стало можливо говорити про появу нової мережної епохи. Виникає новий тип суспільства - мережеве суспільство, яке є соціальною структурою, що характеризує інформаційну епоху розвитку суспільства. Його генезис в значній мірі обумовлений ходом історії, а особливо тим, що на початку 70-х років XX сторіччя у світі паралельно відбувалися три незалежних один від одного процеси: інформаційно-технологічна революція; культурні та соціальні рухи 60-70-х років; кризи, що призвели до перебудови двох існуючих соціально-економічних систем - капіталізму та етатизму. На сьогодні нова соціальна структура у вигляді мережевого суспільства, характерна для більшої частини планети та заснована на новій економіці.

Соціальне новоутворення - мережеве суспільство - репрезентується у різних проявах і демонструє істотні відмінності в тому, що стосується результатів прогресу мережевого суспільства для життя людей. Специфіка трансформаційних змін залежить від історико-культурних і інституційних факторів і дані реорганізаційні процеси приносять як позитивні прогресивні, так i негативні наслідки. Опір розвитку мережевого суспільства, що виникає в умовах сьогодення, пов'язаний з незадоволеними вимогами людства. Інтернет - «...це інформаційна технологія і соціальна форма, яка втілює в собі інформаційну епоху так само, як електричний двигун був важелем соціальних і технічних змін індустріальної епохи» [1], це та технологія, що поступово стає основою комунікаційних шляхів мережевого суспільства. Комп'ютерні технології надають нові обриси поняттю мережі: мережа - це не тільки спосіб транспортування інформації, але і можливість іiі обробки. Інтегральні мережі комунікаційних взаємодій ЕОМ створили особливу форму розподіленої 
комунікації, яку виявилося можливим спроектувати на соціальну комунікацію.

Поняття мережевого суспільства все частіше зустрічається в працях філософів та соціологів, присвячених сучасній постіндустріальній епосі (П. Бурдьє, Ж. Дельоз, М. Кастельс). Використовуючи поняття мережі, слід заглибитись в складну галузь інформації та комунікації, адже мережа, як зазначав А. В. Назарчук, «є технічним феноменом інформації та комунікації, в основі концепції мережевого суспільства лежить уявлення про інформацію як знання, яке породжує зміни в системі» [16]. Генерування знання і інформаційні технології залежать від доступу до відповідної технологічної інфраструктури, а також від якості людських ресурсів, від їх здатності управляти новітніми інформаційними системами.

Провідні науковці Інституту розвитку інформаційного суспільства визначили власне мережеве суспільство як «суспільство, в якому значна частина інформаційних взаємодій відбувається за допомогою електронних мереж» [17]. За М. Кастельсом, «мережеве суспільство - тип інформаціонального суспільства, відмінною рисою якого є мережева логіка його базової структури» [18]. Розглядаючи ті ж тенденції розвитку суспільства, Д. Тапскотт називає прийдешнє і нинішній час епохою мережевого інтелекту, справедливо відзначаючи, що важливим аспектом стає об'єднання в мережу людського інтелекту [19].

В основі концепції мережевого суспільства лежить уявлення про інформацію як знання, які породжують конструктивні зміни системи. Інформація розуміється як характеристика можливостей системи. Інформація є знання обмеженості існуючих можливостей.

Найбільшу популярність в даний час в літературі про мережеве суспільство мають роботи М. Кастельса. Свої роздуми про мережеве суспільство Кастельс вбудовує в ширший контекст технологічної революції і теорії інформаційного суспільства.

Кастельс констатує факт трансформації соціальності в сучасному суспільстві. Соціолог використовує визначення спільноти Б. Велмана, що включає в себе поняття мережі: «Співтовариства - це мережі міжособистісних зв'язків, що забезпечують соціальну взаємодію, підтримку, інформацію, почуття приналежності до групи і соціальну ідентичність» [20]. Якщо основу всякого людського співтовариства становила прихильність людини до місця проживання і роботи, то трендом останнього століття $€$ ослаблення цієї прихильності і перехід до слабших екстериторіальних соціальних зв'язків. Люди втрачають зв'язки $з$ локальними спільнотами не тільки в силу нових комунікаційних можливостей, але і в силу того, що вони реалізують особисті потреби, спираючись на ці нові можливості. Цей принцип побудови спільнот М. Кастельс називає мережевим індивідуалізмом, «персоналізуємим співтовариством». Визначає мережу, як систему, що організує процес комунікації. Теорія мереж визначає розуміння соціальності, трактуючи соціальний контакт як бінарну комунікацію, комунікацію між передавальної і приймаючої сторонами.
Специфіка стратегії дослідження мережевого суспільства в тому, що вона в першу чергу бажає мати справу з технологіями, з питанням «як». Як змінюється життя індивіда, організації, груп; як і за допомогою чого здійснюється побудова мереж; як функціонують мережі. Мережі - це завжди конгломерати об'єктів, це взаємодії між ними за допомогою повідомлень. Мережеві інститути і мережеві підприємства - ті, хто, власне, формує цілі комунікації в рамках своєї функціональної діяльності. Це новий тип організацій, здатний проектувати себе зовні і множитися допомогою клонування.

У сучасному суспільстві стрімко зростає значення гетерогенних мережевих структур, що з'єднують індивідів, організації, регіони і держави. Це зумовлює перетворення в українському та європейських суспільствах: бізнесі, науці, освіті, політиці, та інших сферах. У міру того, як мережеві форми організації поширюються, а структура мереж ускладнюється, теорія і методи мережевого аналізу привертають все більшу увагу дослідників, що працюють в галузі соціальних, когнітивних, економічних, політичних наук, менеджменту та культурології. Мережі транскордонних взаємодій науки, освіти та бізнесу представляють у цьому відношенні особливий інтерес, оскільки сприяють довгостроковій соціальній та економічній стійкості. Дана галузь досліджень включає в себе розробку інструментарію нелінійного управління, відповідного специфіці самоорганізованих мережевих інноваційних структур.

Оскільки знання і комунікація лежать в основі інновацій та креативності, обидва компонента даного дослідницького напрямку складають нерозривну єдність.

Мережеві структури, що засновані на горизонтальних взаємних зв'язках, створюють ефект синергії, стимулюючи творчу взаємодію ланок, що входять у мережу. Головні переваги мережевої форми - креативність, гнучкість і мультиплікативний ефект. До появи сучасних інформаційних технологій такого роду взаємодія могла бути досягнута переважно шляхом особистого спілкування, що обмежувало розміри мережевих структур. Інформаційна революція дала змогу різко розширити масштаби мережевої взаємодії, надати їй транснаціонального і навіть глобального характеру. Мережі перетворилися в каркас глобалізації. Вони охоплюють усі найважливіші сфери суспільної діяльності - інформаційну, виробничу, фінансову, ідеологічну, політичну - i функціонують на різних рівнях [13].

Розглянемо основні характеристики та особливості мережевого суспільства:

- мережі є найбільш успішними та конкурентоспроможними проектами в економіці, фінансах, освіті, культурі, політиці;

- знання та інформація є головними джерелами конкурентоспроможності;

- в мережі головною діючою особою $\epsilon$ активна особистість, довкола якої формуються союзи та коаліції;

- не лише мережі об'єднують соціальних суб'єктів, але і ці суб'єкти, включаючись в різні мережі, здатні сполучати їх. Сучасні мережі здатні розгортатися і стискатися, відкриватися і закриватися, 
утворювати найхимернішу геометрію обхвату, оперативно включати нових учасників і звільняти їх;

- ієрархія в мережі децентралізована (аж до феномену «розщепленого лідерства»), тому існують декілька лідерів; формальні;

- неформальні відносини іноді важливіші за

- мережева організація не має структурних підрозділів усередині себе, оскільки є єдиною цілісністю;

- структури в мережевому суспільстві мінливі, існують недовго, тобто, якщо змінюються завдання, то руйнуються вчорашні союзи та виникають нові;

- структури підпорядковуються їх творцю, який вирішує чи виникати їм, чи розпадатися;

- праця стає більш індивідуальною, відбувається децентралізація робочих місць;

- інформаційні технології створюють зв'язки, які породжують нелінійності і викликають багато нових можливостей у формі біфуркацій;

- стало можливим широке розповсюдження ГРІД-технологій.

ГРІД (Grid) - новітні інформаційно-обчислювальні технології, які мають реальну перспективу найширшого застосування в різноманітних галузях науки, освіти, економіки та гуманітарній сфері. Ocновною ідеєю ГРІДу є «колективне використання географічно розподілених комп'ютерних ресурсів великої потужності, об'єднаних швидкісними каналами зв'язку й організованих таким чином, що для окремого користувача ця мережа сприймається як один гігантський комп'ютер» [21].

Нині становлення ГРІД-технологій за темпами розвитку випереджає Інтернет, адже наявність національної ГРІД-інфраструктури є потужним інтегруючим чинником, що відіграє ключову роль для налагодження більш тісних і плідних взаємостосунків у науці, освіті, культурі та бізнесі.

В даний час відомі три найважливіших інформаційних технології: Інтернет (як мережа комп'ютерів, об'єднаних каналами з протоколами ТСР/IP для зв'язку), Веб (як мережа сайтів, що використовують гіперпосилання для переходів і Грід (як обчислювальної інфраструктури, яка забезпечує безперебійний доступ до обчислювальних потужностей і ресурсів зберігання даних, розподілених по всьому світу).

Виділяючи риси та особливості мережевого суспільства, вчені звертаються і до його проблем, i до виникаючих протиріч. Так, М. Кастельс звертає увагу на низку незадоволених вимог, які, з одного боку, гальмують розвиток суспільства і відображають його деякий опір, а з іншого - $є$ сферами переформатування соціальної структури. Такою вимогою і протиріччям $є$ свобода. 3 одного боку, Інтернет відкриває кордони комунікацій, а з іншого, можливість отримання контролю над свободою людини, що володіє інфраструктурою мереж, ставить під загрозу, зокрема, свободу комунікації. Протиріччям є і прагнення людей до створення штучного інтелекту, що перевершує людини по швидкості мислення, здібностям до тих чи інших операцій і ряду інших параметрів, і одночасно побоювання технологічних монстрів, що вийшли 3-під контролю людини. Незадоволеною залишається і вимога до сучасної освіти, а саме до розвитку у дитини спеціальних інтелектуальних здібностей до навчання протягом усього життя, до знаходження, використання, обробці цифрової інформації та виробництва на ії основі необхідних для тієї чи іншої мети знань. М. Кастельс підкреслює, що для цього необхідна нова педагогіка, що базується на інтерактивності і розвитку незалежних здібностей до навчання i мислення, а також сприяє вихованню характеру [22].

Відповіддю на протиріччя, позначене М. Кастельсом у 2001 р., став спалах розвитку онлайносвіти. Стартувала онлайн-освіта 3 простих дистанційних форм, що є прямими аналогами традиційних заочних курсів. Їх розвиток йшов паралельно 3 поширенням нових форм передачі інформації та отримання зворотного зв'язку. Процес йшов не тільки в неформальному секторі, а й у формальному. 32008 року по теперішній час з'являється велика кількість освітніх платформ, що пропонують MOOC (Massive Open Online Course) не тільки у формі самоосвіти, але і курсів, після яких слухач може пройти сертифікацію в одному з ВУЗів. Одним з показників опору і неефективності такої форми на даному етапі є велика кількість людей, які не доходять до кінця навчання на подібних курсах або не проходять заключних випробувань. За даними досліджень Британського відкритого університету, в середньому завершують навчання на курсі 40 \% з зареєстрованих, причому у більшості курсів відсоток успішних учнів не більше $13 \%$ [20]. Спробою вирішення цієї проблеми стало створення SOOC - селективних онлайн-курсів. Особливості селективних курсів, по-перше, полягають у тому, що для вступу потрібно пройти деякий відбір за різними критеріями, а по-друге, вони платні для учнів. Досліджень за результативністю SOOC на даний момент немає, але зрозуміло, що в такій системі практично немає відмінностей від очної системи формальної освіти. Відзначимо, що і у випадку відкритих, і в разі селективних курсів рівень успішності залежить від мотивації і самоорганізації людей, які планують вчитися. В середньому на кожний відкритий курс записується близько 20000 чоловік, тому питання про залучення в відкриту освіту гостро не стоїть, проблема в утриманні вже заявилися [23]. Особливістю такої системи глобальної освіти і науки стає посилене зростання конкуренції та міграції викладачів i студентів. Закон порівняльних переваг припускає, що така мобільність сприятиме спеціалізації в суспільстві, адже саме спеціалізація і стандартизація - два основних взаємодоповнюючих аспекти глобалізації науки освіти.

Перерозподіл відстаней, порядок виникнення i підтримки слабких і сильних зв'язків у мережі встановлюють нові принципи побудови взаємин в мережевому суспільстві. Принципами такої мережі є масове співробітництво (mass collaboration) і виробництво на рівних (peer production): все більша кількість продуктів виробляється за допомогою об'єднання зусиль величезної кількості людей, і все частіше ці люди не $є$ співробітниками якої-небудь однієї корпорації, а беруть участь у проектах в якості вільних фахівців. Такими продуктами $є$ не тільки програмні коди 
або онлайн-енциклопедії, є приклади складних коллаборативних проектів, пов'язаних 3 аналізом генома людини або проектуванням літака; мережева структура простежується і в сфері освіти, в сільському господарстві. Краудсорсингові технології - технології залучення до вирішення питання великої кількості людей - стають важливим елементом організації результативної діяльності. Відомо, що в неорганізованому стані група може поступатися за інтелектуальними здібностями навіть індивіду. Тільки облік можливостей кожного учасника колективу дозволяє результативно і ефективно використовувати інтелектуальні здібності в групі. Таким чином, процес цілеспрямованого отримання будь-якого інтелектуального продукту в мережевому суспільстві логічно розбивається на два етапи: етап розвитку людських здібностей в тому руслі, про яке говорить М. Кастельс, і етап конструктивного об'єднання самоорганізованих учасників у процесі міжмережевої взаємодії. Для того щоб домогтися такого ефекту, тобто для вибудовування широкою горизонтальною мережі колективного інтелекту і здібностей, що працює в заданому напрямку, необхідна насамперед мотивація і самоорганізація кожного учасника. Так як мова йде про великі маси людей різного віку, життєвого досвіду, менталітету і т. д., котрі самонавчаються і взаємодіють, то виникає питання про певну універсальність мотивуючого і організуючого інструменту.

Одним 3 найважливіших завдань освітньої політики держави на сучасному етапі виступає організація всебічного партнерства. Це означає, зокрема, i розвиток мережевої взаємодії на різних рівнях системи освіти.

Сьогодні під мережевою взаємодією розуміється система горизонтальних і вертикальних зв'язків, що забезпечує доступність якісної освіти для всіх категорій громадян, варіативність освіти, відкритість освітніх організацій, підвищення професійної компетентності педагогів і використання сучасних інформаційно-комунікаційних технологій (IКТ).

Мережева взаємодія дозволяє:

- розподіляти ресурси при загальному завданню діяльності;

- спиратися на ініціативу кожного конкретного учасника;

- здійснювати прямий контакт учасників один 3 одним;

- вибудовувати різноманітні можливі шляхи руху при спільності зовнішньої мети;

- використовувати загальний ресурс мережі для потреб кожного конкретного учасника.

В даний час мережева взаємодія є одним 3 потужних ресурсів інноваційної освіти, заснованого на наступних принципах:

По-перше, мережа - це можливість просування продуктів інноваційної діяльності на ринок освітніх послуг i, таким чином, отримання додаткового фінансування.

По-друге, мережева взаємодія дозволяє посилювати ресурс будь-якого інноваційного закладу за рахунок ресурсів інших установ. Мережа допомагає знайти прецеденти, отримати експертизу власних ро- зробок, розширити перелік освітніх послуг для студентів, в тому числі, за допомогою реалізації освітніх програм в мережевій формі.

Мережа створюється на добровільній основі, утримується загальною проблематикою та інтересами всіх членів мережі. Таким чином, мережа завжди $\epsilon$ результатом проектного задуму, оскільки учасники повинні брати участь в єдиному цілеспрямуванні, погоджувати механізми і схеми взаємодії, домовлятися про результати діяльності

Мережева взаємодія сьогодні стає сучасною високоефективною інноваційною технологією, яка дозволяє освітнім установам не тільки виживати, але й динамічно розвиватися. Важливо зауважити, що при мережевій взаємодії відбувається не тільки поширення інноваційних розробок, а також йде процес діалогу між освітніми установами та процес відображення в них досвіду один одного, відображення тих процесів, які відбуваються в системі освіти в цілому [24].

Інновації в умовах освітньої мережі набувають еволюційний характер, що пов'язано з безперервним обміном інформацією та досвідом, і відсутністю обов'язкового впровадження. Досвід учасників мережі виявляється затребуваним не тільки як приклад для наслідування, а також в якості індикатора, який дозволяє побачити рівень власного досвіду і доповнити його чимось новим, сприяючим ефективності подальшої роботи. Мережева взаємодія - це система зв'язків, які дозволяють розробляти, апробувати та пропонувати професійному педагогічному співтовариству інноваційні моделі змісту освіти та управління системою освіти; це спосіб діяльності по спільному використанню ресурсів.

За мережевим підходом в управлінні освітою 3'являються такі принципи як добровільність встановлення зв'язків, рівноправність, взаємодопомога, партнерство, відсутність ієрархічного керівництва. Таким чином, виникає мережа закладів освіти, що характеризується різноманітністю діяльності та породженням нових людських стосунків. Позитивною стороною появи мережевої системи освіти є розвиток освіти як соціального інституту, зберігання умов його все загальності, а також динамізація інтегративних процесів між різними освітніми організаціями і забезпечення процесу формування загальних принципів, загального смислового поля в сучасній освіті. За Кастельсом, мережа - це «...сукупність пов'язаних між собою вузлів. Мережа дозволяє моментально і майже без зайвих витрат часу, сил та енергії встановити велику кількість прямих контактів і цим полегшує виявлення партнерів» [25].

Можна стверджувати, що 3 появою мережевого суспільства, суспільства інформаціонального знання отримуються ефективніше та доступніше. Саме за допомогою знань соціальні інститути стають відкритішими, якість та конкурентоспроможність освіти підвищується, отримання освітньої кваліфікації зростає. Роль знань, освіти у побудові мережевого суспільства важко переоцінити як і вплив мережевого суспільства на особливості розвитку освітньої системи. Адже в процесах модернізації освітнього простору актуалізується зведення системи отримання освіти 
молоддю України до одного європейського стандарту, проте при цьому не враховується важливість виховання за допомогою освіти неповторної культурної ідентичності в різних народів, верств населення, націй, регіональних спільнот, етносів. Зрозумілим стає пріоритетність включення до реорганізаційної політики в сфері освіти такого важливого складника як врахування культурної приналежності особистості, що навчається, iї неповторної картини світу, перебудові наявних інститутів управління до умов мережевого суспільства.

\section{5 Результати досліджень}

Побудова мережного суспільства носить глобальний характер, що зумовлено розвитком комп'ютерних мереж та телекомунікацій, завдяки яким реалізуються можливості горизонтального спілкування між індивідами і групами, що робить потенційною мережевою структурою значну частину світу. Глобальне інформаційне суспільство побудоване значною мірою за принципом мереж [26]. Визначаючи сутність мережного суспільства, слід застосовувати узагальнені визначення М. Кастельса, який зазначав, що мережне суспільство - це специфічна форма соціальної структури, яка характерна для інформаційного суспільства [1]. Також для глибшого розуміння цього поняття необхідно враховувати існування певних факторів становлення сучасного суспільства, які домінують у його визначенні як мережного. Серед них можна виділити: інформатизацію суспільства, використання інформаційних технологій (мережних зокрема), збільшення частки комп'ютерних комунікацій, створення глобального інформаційного простору, i, відповідно, зміну самої соціальної реальності. В наш час все більше підвищується роль мережних комунікацій, що зумовлює подальше вивчення сучасного суспільства як мережного, роль та місце нових інформаційних технологій та визначення їх впливу на розвиток поінформованого суспільства в цілому.

Сучасний етап суспільного розвитку людства тлумачиться дослідниками як інформаційне суспільство, основним ресурсом якого є інформація. Інформація стає предметом масового споживання з певною цінністю. Освіта розглядається як середовище інформаційного обміну. Саме таке середовище передбачає накопичення, генерування, засвоєння та передачу нової інформації, актуалізує проблему зміни типів та способів мислення і поведінки особистості, моральних орієнтирів, культурних ідеалів. Беручи до уваги той факт, що проблема розвитку освітньої галузі в індустріальному суспільстві є складною, багатогранною й актуальною для українського суспільства та освіти зокрема, буде доцільно продовжити дослідження з окресленого питання.

\section{6 Висновки}

Становлення інформаційного суспільства призвело до загальної комп'ютеризації та впровадження інформаційно-телекомунікаційних технологій в сферу освіти. Інформація та знання стають ключовими джерелами продуктивності і конкурен- тоспроможності, еволюції соціуму на сучасному етапі. Залучення основних аспектів теорії інформаціонального суспільства Кастельса і концепції мережевого суспільства до проблеми модернізації освітнього простору, дозволяє, на наш погляд, виявити закономірність формування специфіки культурної ідентичності у певному типі суспільства. Концептуальна стратегія Кастельса дозволяє дослідити особливості трансформаційних процесів, що репрезентують перехідний стан соціальних інститутів до нових форм діяльності, впливаючи на культурну ідентичність особистості інформаціонального суспільства. Зазначимо, що в процесі модернізації сучасного освітнього простору перспективним $є$ формування таких освітніх стратегій, які б враховували багатоаспектність і гетерогенність феномену культурної ідентичності в умовах інформаціонального розвитку сучасного суспільства, сприяючи відновленню балансу між культурно-національною ідентичністю і глобалізаційними процесами.

\section{Література}

1. Кастельс, М. Информационная эпоха, общество и культура [Текст] / М. Кастельс. - М.: ГУВШЭ, 2000. - 608 с.

2. Masuda, Y. The Informational Society as PostIndustrial Society [Text] / Y. Masuda // World Future Society. $-1981 .-$ P. 33

3. Белл, Д. Грядущее постиндустриальное общество. Опыт социального прогнозирования [Текст] / Д. Белл. M.: Academia, 1999. - $956 \mathrm{c}$.

4. Тоффлер, О. Адаптивная корпорация [Текст] / О. Тоффлер; под ред. В. Л. Иноземцева. - Новая постиндустриальная волна на Западе. - М.: Academia, 1999. - 453 с.

5. Абдеев, Р. Ф. Философия информационной цивилизации: диалектика прогрессивной линии пазвития ка гуманитарная общечеловеческая философия для XX века [Текст] / Р. Ф. Абдеев. - М., 1994. - 334 с.

6. Иноземцев, В. Л. Современное постиндустриальное общество: природа, противоречия, перспективы [Текст] / В. Л. Иноземцев. - М.: Логос, 2000. - 304 с.

7. Иноземцев, В. Л. Пределы «догоняющего развития» [Текст] / В. Л. Иноземцев. - М.: ЗАО «Издательство «Экономика», 2000. - 295 с.

8. Дука, С. И. Информационное общество. Социогуманитарные аспекты [Текст] / С. И. Дука. - СПб.: Издательство Санкт-Петербургского университета, 2004. - 172 с.

9. Бианки, В. А. Психологические аспекты функционирования власти в сетевых структурах [Текст] / В. А. Бианки. - Режим доступа: http://www.myshared.ru/slide/316368/

10. Тоффлер, О. Адаптивная корпорация [Текст] / О. Тоффлер; под ред. В. Л. Иноземцева. - Новая постиндустриальная волна на Западе. - М.: Academia, 1999. - 453 с.

11. Гэлбрейт, Дж. Новое индустриальное общество [Текст] / Дж. Гэлбрейт. - М.: Прогресс, 1969. - 480 с.

12. Белл, Д. Грядущее постиндустриальное общество [Текст] / Д. Белл. - М.: Academia, 1999. - 956 с.

13. Иванов, Н. Глобализация и общество: проблемы управления [Текст] / Н. Иванов // Мировая экономика и международные отношения. - 2008. - № 4. - С. 3-15.

14. Бейлін, М. В. Техніка і технології: сутнісні характеристики [Текст] / М. В. Бейлін // Практична філософія. 2008. - № 2 (28). - С. 28-32.

15. Наумкина, Е. А. Информационное общество и модернизация образования [Текст]: монография / Е. А. Наумкина; ин-т философии им. Г. С. Сковороды НАН Украины. - К.: ПАРАПАН, 2008. - С. 267-280. 
16. Ічанська, О. М. Становлення особистісної ідентичності в ранньому юнацькому віці [Текст]: автореф. дис. ... канд. психолог. наук / О. М. Ічанська; Національний педагогічний університет ім. М. П. Драгоманова. - К., 2002. -20 с.

17. Кастельс, М. Становление общества сетевых структур [Текст] / М. Кастельс. - Новая постиндустриальная волна на Западе. - М.: Academia, 1999. - С. 492-505.

18. Dzvinchuk, D. Osvita v istoryko-filosofs'komu vymiri: tendencii' rozvytku ta upravlinnja [Text] / D. Dzvinchuk. - K.: ZAT «Nichlava», 2006. - 101 p.

19. Тапскотт, Д. Электронно-цифровое общество: Плюсы и минусы эпохи сетевого интеллекта [Текст] / Д. Тапскотт. - Киев - Москва: «INT Пресс» - «Рефл-бук», 1999. -403 c.

20. Кастельс, М. Галактика Интернет: Размышления об Интернете, бизнесе и обществе [Текст] / М. Кастельс; перевод с англ. А. Матвеева; под ред. В. Харитонова. Екатеринбург: У- Фактория, 2004. - 328 с.

21. Красюк, С. ГРІД-технології: сьогодення і перспективи [Текст] / С. Красюк // Науковий світ. - 2009. № 7. - C. 2-3.

22. Бард, А. Новая правящая элита и жизнь после капитализма [Текст] / А. Бард, Я. Зодерквист. - СПб.: Стокгольмская школа экономики в СПб., 2004. - 252 с.

23. Емелин, В. Ризома и Интернет [Электронный pecypc] / В. Емелин // Глобальная сеть и киберкультура. Режим доступа: http://emeline.narod.ru/rhizome.htm

24. Мельник, Н. А. Освітній округ: основні завдання та функції [Текст] / Н. А. Мельник // Народна освіта. 2012. - Вип. 3 (18). - Режим доступу: http://narodnaosvita. kiev.ua/Narodna_osvita/vupysku/18/statti/melnik.htm

25. Castells, M. The Power of Identity. Vol. 2 [Text] / M. Castells. - Information Age: Economy, Society and Culture. - Blackwell Publishing Ltd, 2004. -610 p.

26. Паршин, П. Глобальное информационное общество и мировая политика [Текст] / П. Паршин // Аналитические доклады ИМИ. - 2009. - Вып. 2 (23). - 41 с. - Режим доступа: http://mgimo.ru/files/138392/ad-23.pdf

\section{References}

1. Castells, M. (2000). The Information Age, society and culture. Moscow: Higher School of Economics, 608.

2. Masuda, Y. (1981). The Informational Society as Post-Industrial Society. World Future Society, 33.

3. Bell, D. (1999). The coming post-industrial society. Experience in social forecasting. Moscow: Academia, 956.

4. Toffler, O.; Inozemtsev, V. L. (Ed.) (1999). Adaptive Corporation. The new wave of post-industrial West. Moscow: Academia, 453.

5. Abdeev, R. F. (1994). Philosophy of information civilization: the dialectic of a progressive line pazvitiya ka humanitarian philosophy to universal human twentieth century. Moscow, 334 .

6. Inozemtsev, V. L. (2000). Modern post-industrial society: nature, contradictions and prospects. Moscow: Logos, 304.
7. Inozemtsev, V. L. (2000). The limits of "catch-up". Moscow: ZAO "Publishing house" Economy ", 295.

8. Duca, S. I. (2004). Information society. Social and humanitarian aspects. Sankr-Peterburg: Publishing house of St. Petersburg State University, 172.

9. Bianchi, V. A. Psychological aspects of the power of network structures. Available at: http://www.myshared.ru/slide/ $316368 /$

10. Toffler, O.; Inozemtsev, V. L. (Ed.) (1999). Adaptive Corporation. The new wave of post-industrial West. Moscow: Academia, 453.

11. Galbraith, J. (1969). New Industrial State. Moscow: Progress, 480.

12. Bell, D. (1999). The coming post-industrial society. Moscow: Academia, 956.

13. Ivanov, N. (2008). Globalization and Society: management problems. World Economy and International Relations, 4, 3-15.

14. Beylin, M. V. (2008). Tehnika i tehnologii: sutnisni characteristics. Filosofiya practicality, 2 (28), 28-32.

15. Naumkin, E. A. (2008). Information society and modernization of education. Education \& Science: Modern Transformation. Kyiv: PARAPAN, 267-280.

16. Ichanska, O. M. (2002). Formation osobistisnoi identichnosti in Rann yunatskomu vitsi. Kyiv, 20.

17. Castells, M. (1999). Becoming society network structures. A new wave of post-industrial West. Moscow: Academia, 492-505.

18. Dzvinchuk, D. (2006). Osvita v istoryko-filosofs'komu vymiri: tendencii 'rozvytku ta upravlinnja. Kyiv: ZAT «Nichlava», 101.

19. Tapscott, D. (1999). The digital society: Pros and cons of the era of network intelligence. Kyiv - Moscow: INT Press - Refl-book, 403.

20. Castells, M.; Kharitonov, V. (Ed.) (2004). Internet Galaxy: Reflections on the Internet, business and society. Yekaterinburg: Y Factoria, 328.

21. Krasiuk, S. (2009). GRID-tehnologii: sogodennya i Vista. NAUKOVO's World, 7, 2-3.

22. Bard, A., Zoderkvist, J. (2004). The new ruling elite and life after capitalism. Sankt-Peterburg: Stockholm School of Economics in St. Petersburg, 252.

23. Emelin, V. Rhizome and the Internet. Global Network and cyberculture. Available at: http://emeline.narod.ru/ rhizome.htm

24. Miller, N. A. (2012). Osvitniy District: osnovni zavdannya that funktsii. Narodna Osvita. 3 (18). Available at: http://narodnaosvita.kiev.ua/Narodna_osvita/vupysku/18/statti/ melnik.htm

25. Castells, M. (2004). The Power of Identity. Vol. 2. Information Age: Economy, Society and Culture. Blackwell Publishing Ltd, 610.

26. Parshin, A. P. (2009). Global Information Society and World Politics. Analytical reports them, 2 (23), 41. Available at: http://mgimo.ru/files/138392/ad-23.pdf

Рекомендовано до публікації д-р філол. наук, професор Когут О. В. Дата надходження рукопису 23.10.2015

Заміховська Олена Леонідівна, кандидат технічних наук, доцент, кафедра комп'ютерних технологій в системах управління і автоматики, Івано-Франківський національний технічний університет нафти і газу, вул. Карпатська, 15, м. Івано-Франківськ, Україна, 76019 